\title{
Nodulosphaeria aconiti, a new host record on Artemisia sp. in Uzbekistan
}

\section{Pasouvang $P \quad{ }^{1,2,3}$, Karunarathna $\mathbf{A}^{1,4}$, Mapook $\mathbf{A}^{1}$, Gafforov $\mathbf{Y}^{5}$, Norimova $G^{6}$, Sibounavong $P^{3}$ and Jayawardena RS $^{1,2, *}$}

\author{
${ }^{1}$ Center of Excellence in Fungal Research, Mae Fah Luang University, Chiang Rai 57100, Thailand \\ ${ }^{2}$ School of Science, Mae Fah Luang University, Chiang Rai 57100, Thailand \\ ${ }^{3}$ Plant Protection Unit, Department of Agronomy, Faculty of Agriculture, National University of Laos (NUOL), P.O \\ Box: 7322, Dongdok, Vientiane, Lao PDR \\ ${ }^{4}$ Department of Entomology and Plant Pathology, Faculty of Agriculture, Chiang Mai University, Chiang Mai 50200, \\ Thailand \\ ${ }^{5}$ Laboratory of Mycology, Institute of Botany, Academy of Sciences of the Republic of Uzbekistan, 32 Durmon Yuli \\ Street, Tashkent 100125, Uzbekistan \\ ${ }^{6}$ Department of Botany, Samarkand State University, University blv. 15, Samarkand, 140104, Uzbekistan
}

Pasouvang P, Karunarathna A, Mapook A, Gafforov Y, Norimova G, Sibounavong P, Jayawardena RS 2021 - Nodulosphaeria aconiti, a new host record on Artemisia sp. in Uzbekistan. Plant Pathology \& Quarantine 11(1), 191-199, Doi 10.5943/ppq/11/1/20

\begin{abstract}
This study reports a novel host and a geographical record of Nodulosphaeria aconiti from Artemisia sp. (Compositaceae) from the Jizzakh Region of Uzbekistan. Phylogenetic analyses of concatenated LSU, SSU, ITS, tef1- $\alpha$, and $r p b 2$ sequence data revealed that our isolate is closely related to the $N$. aconiti, which was further proven from morphology. The detailed descriptions and illustrations of $N$. aconiti with an updated phylogenetic tree for Nodulosphaeria are provided herein.
\end{abstract}

Keywords - Ascomycetous microfungi - Central Asia - multigene phylogeny - taxonomy terrestrial saprobe

\section{Introduction}

Phaeosphaeriaceae was introduced by Barr (1979) is one of the largest and important family in Pleosporales, which includes economically important phytopathogens (e.g. Neosetophoma, Parastagonospora, Phaeosphaeria, Phaeosphaeriopsis, Setophoma, Wojnowicia and Xenoseptoria) (Carson 2005, Arzanlou \& Crous 2006, Quaedvlieg et al. 2013, Phookamsak et al. 2014). Phaeosphaeriaceae comprises more than 82 genera (Wijayawardene et al. 2020) and 794 species, which can be saprobic, hyperparasitic, endophytic and pathogenic on monocotyledons (e.g. Cannaceae, Cyperaceae, Juncaceae, Poaceae) (Hyde et al. 2013, Phookamsak et al. 2014, Hongsanan et al. 2020) and dicotyledons (e.g. Ranunculaceae, Caprifoliaceae, Apiaceae) (Mapook et al. 2016). The introduction of numerous novel genera and species into this family resulted in a rapid taxonomic expansion of the Paheosphaeriaceae (Li et al. 2015).

Nodulosphaeria was introduced by Rabenhorst (1858) with $N$. hirta Rabenh. as the type species. The genus is characterized by the ascomatal apex lined with brown setae, three-to multi- 
septate ascospores, with a swollen cell and some with terminal appendages (Holm 1961, Shoemaker 1984). Clements \& Shear (1931) considered Nodulosphaeria as a synonym of Leptosphaeria. The relationship between Leptosphaeria, Nodulosphaeria and Ophiobolus was emphasized by Holm (1957). Due to the presence of hyaline ascospores with one swollen cell, Shoemaker (1976) re-circumscribed Nodulosphaeria and transferred various species to Ophiobolus. Barr (1979) accommodated Nodulosphaeria in Phaeosphaeriaceae. Mapook et al. (2016) did a morphology and phylogeny-based study to confirm the placement of novel host and geographical record of Nodulosphaeria within Phaeosphaeriaceae. Phookamsak et al. (2017) studied the taxonomy and phylogeny of Ophiobolus along with Nodulosphaeria and emphasized the close relationship between Ophiobolus and Nodulosphaeria using multigene phylogeny including both ribosomal and protein-coding genes. Nodulosphaeria species are widely disseminated through the northern Hemisphere and comprise saprobic, endophytic and pathogenic species associated with a wide variety of substrates (Mapook et al. 2016, Tibpromma et al. 2017, Wijayawardene et al. 2017, Farr \& Rossman 2021). There are 46 epithets listed under Nodulosphaeria in Index Fungorum (2021).

Our recent studies on fungi from Uzbekistan revealed several novel genera and species within Pleosporales (Wanasinghe et al. 2018, Pem et al. 2018, 2019, Gafforov et al. 2019). Studies of fungi on Artemisia sp. revealed Nodulosphaeria dolioloides from Sweden (Shoemaker 1984) and Bulgaria (Stoykowv 2004), based on morphological and molecular data.

This study identified the taxonomic and phylogenetic placement of Nodulosphaeria aconiti based on descriptive morphology and multi-gene phylogeny (LSU, SSU, ITS, tef1- $\alpha$ and $r p b 2$ ). Further, the updated phylogenetic tree for Nodulophaeria is provided herein.

\section{Materials \& Methods}

\section{Isolates and morphology}

Specimens were collected from dead stems of Artemisia sp. from Zaamin National Nature Park, Zaamin District, Jizzakh Region, Uzbekistan. The samples were taken to the laboratory in paper bags. Specimens were observed, photographed, measured and illustrated as described by (Wanasinghe et al. 2020). Single spore isolations were obtained using the methods described in (Senanayake et al. 2020). The growth rates and culture characteristics were recorded after one week and four weeks. The cultures were deposited in the Culture collection of Kunming Institute of Botany (KUMCC). The dried specimens were deposited in the Tashkent Mycological Herbarium (TASM) of the Institute of Botany, Academy of Sciences of Uzbekistan, Tashkent and the herbarium of Kunming Institute of Botany Academia Sinica (HKAS).

\section{DNA extraction, PCR amplification and sequencing}

DNA was extracted from mycelium as described in (Senanayake et al. 2020). Mycelium was ground and DNA was extracted using the Biospin Fungus Genomic DNA Extraction Kit-BSC14S1 (BioFlux, China) following the instructions of the manufacturer. Polymerase Chain Reaction (PCR) was performed for five gene regions, the internal transcribed spacers region of ribosomal DNA (ITS: ITS5/ITS4) (White et al. 1990), large subunit nuclear ribosomal DNA (LSU: LR0R/LR5) (Vilgalys \& Hester 1990), small subunit nuclear ribosomal DNA (SSU: NS1/NS4) (White et al.1990), translation elongation factor 1-alpha gene (tef1- $\alpha$ : EF1-983F/EF1-2218R) (Rehner \& Buckley 2005) and second-largest subunit (rpb2: fRPB2-5F/ fRPB2-7cR) (Liu et al. 1999). The polymerase chain reaction (PCR) was carried out using the following protocol described in Wanasinghe et al. (2020). The amplified PCR fragments were sent to a commercial sequencing provider (Sangon Biotech Co., Shanghai, China). The nucleotide sequence data acquired were deposited in GenBank (Table 1). 


\section{Phylogenetic analyses}

Sequences generated from different primers of the five gene regions were analyzed with other sequences retrieved from GenBank (Table 1). Sequences with high similarity indices were retrieved from BLAST search to find the closest matches with taxa in Phaeosphaeriaceae and from published data (Mapook et al. 2016). The multiple alignments of all consensus sequences and the reference sequences were aligned with MAFFT v. 7 (http://mafft.cbrc.jp/alignment/server/index.html; Kuraku et al. 2013, Katoh et al. 2019). The alignments were improved manually when necessary using BioEdit v. 7.0.5.2 (Hall 1999). Ambiguous regions were excluded manually from the analyses and gaps were treated as missing data.

The model of nucleotide substitution was performed by using MrModeltest 2.2 (Nylander 2004) for each gene. Bayesian analysis was conducted with MrBayes v. 3.1.2 (Huelsenbeck \& Ronquist 2001) to evaluate Bayesian posterior probabilities (BYPP) (Rannala \& Yang 1996) by Markov chain Monte Carlo sampling (BMCMC). The evolutionary model GTR $+\mathrm{I}+\mathrm{G}$ was used. Six simultaneous Markov chains were run for 2000000 generations and trees were sampled every 100th generation. The distribution of log-likelihood score was examined to determine the stationary phase for each search and to decide if extra runs were required to achieve convergence, using the program Tracer 1.4 (Rambaut \& Drummond 2007). The first 10\% of generated trees were discarded and the remaining $90 \%$ of trees were used to calculate posterior probabilities of the majority rule consensus tree. Maximum likelihood trees were generated using the RAxML-HPC2 on XSEDE (8.2.8) (Stamatakis et al. 2008, Stamatakis 2014) in the CIPRES Science Gateway platform (Miller et al. 2010) using the GTR $+\mathrm{I}+\mathrm{G}$ model of evolution. Phylograms were visualized with FigTree v1.4.0 program (Rambaut 2012) and reorganized in Microsoft PowerPoint (2007).

\section{Results}

\section{Phylogenetic analysis of combined LSU, SSU, ITS, tef1- $\alpha$ and rpb2 sequence data}

Multigene phylogenetic analyses of the combined dataset (LSU, SSU, ITS, tef1- $\alpha$ and rpb2) consisted 34 taxa including selected genera in Phaeosphaeriaceae, our strain, and Phaeosphaeria chiangraina (MFLUCC 13-0231) and P. musae (MFLUCC 11-0133) as outgroup. The RAxML analysis of the combined dataset yielded a best scoring tree (Fig. 1) with a final ML optimization likelihood value of -15022.239399. The matrix had 967 distinct alignment patterns, with $34.74 \%$ of undetermined characters or gaps. Parameters for the GTR + I + G model of the combined ITS, LSU, SSU, tef $1-\alpha$ and $r p b 2$ were as follows: Estimated base frequencies; $\mathrm{A}=0.247933, \mathrm{C}=$ $0.229408, \mathrm{G}=0.267167, \mathrm{~T}=0.255492$; substitution rates $\mathrm{AC}=1.072063, \mathrm{AG}=2.474458, \mathrm{AT}=$ $1.484950, \mathrm{CG}=0.819611, \mathrm{CT}=6.234685, \mathrm{GT}=1.000000 ;$ proportion of invariable sites $\mathrm{I}=$ 0.483111 ; gamma distribution shape parameter $\alpha=0.507896$.

The ML tree generated based on sequence analysis of the combined dataset indicated that our new strain grouped with Nodulosphaeria aconiti (MFLUCC 13-0728) with 68\%/0.99 ML/BYPP.

\section{Taxonomy}

Nodulosphaeria aconiti Mapook, Camporesi \& K.D. Hyde 2016 Index Fungorum number: IF 551942; Facesoffungi number: FoF 00446

Fig. 2

Saprobic on dead herbaceous stems of dried stems of Artemisia sp. noticeable as black dots on the host surface. Sexual morph: Ascomata 160-230 hight $\times 180-250 \mu \mathrm{m}$ diam $(\bar{x}=194-222$ $\mu \mathrm{m}, \mathrm{n}=6$ ). immersed, erumpent at maturity, solitary, scattered, subglobose to obpyriform, coriaceous, dark brown, Ostiole short papillate, with numerous internal dark brown setae. Peridium 10-20 $\mu \mathrm{m}$, comprising 2-3 layers of thick-walled, dark brown cells of textura angularis. Hamathecium comprising 2-2.5 $\mu \mathrm{m}$ wide, cylindrical, septate, branching pseudoparaphyses, anastomosing above the asci. Asci $60-100 \times 8-12 \mu \mathrm{m}(\bar{x}=83-10 \mu \mathrm{m}, \mathrm{n}=15), 8$-spored, bitunicate, cylindrical to cylindric-subclavate, apically rounded with an ocular chamber, slightly curved, with a short, bulbous pedicel. Ascospores 30-36 $\times 3-4 \mu \mathrm{m}(\bar{x}=33-4 \mu \mathrm{m}, \mathrm{n}=11)$, overlapping 2-3-seriate, 
hyaline or pale brown, cylindric-fusiform, tapering towards the rounded ends, 4-septate, broader and constricted at the second cell from the apex, straight to slightly curved, guttulate, smoothwalled, with terminal appendages. Asexual morph: Undetermined.

Culture characteristics - Colonies on PDA, slow-growing, reaching $2 \mathrm{~cm}$ diam, after five weeks at $20^{\circ} \mathrm{C}$, circular, rough margin, creamy, reverse orange, flat on the surface, without aerial mycelium. Hyphae septate, branched, hyaline, thin-walled.

Material examined - Uzbekistan, Jizzakh Region, Zaamin District, Zaamin National Nature Park, Turkestan range of Pamir-Alay Mountains, Qiriqbuloq, dried stems of Artemisia sp. (Compositaceae), 10 July 2019, Yusufjon Gafforov and Guljakhon Norimova, YG-Z51-1 (TASM 6154, HKAS112715, KUMCC 20-0333).

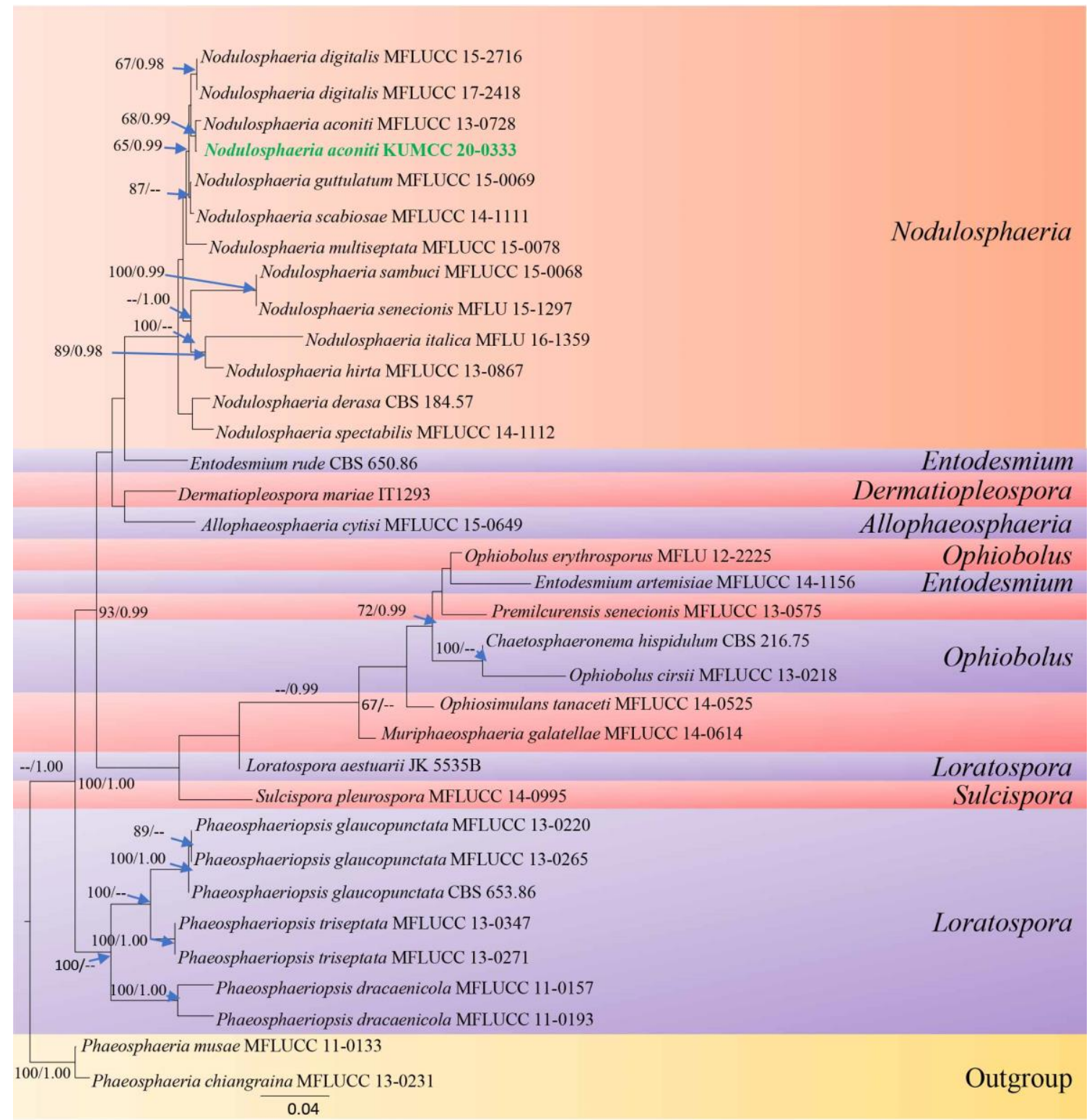

Fig. 1 - The RAxML tree is based on a combined LSU, SSU, ITS, tef1- $\alpha$ and $r p b 2$ partial sequence data. Bootstrap support values for ML equal to or higher than $65 \%$ and Bayesian posterior probabilities equal to or greater than 0.98 are displayed on the nodes. A newly introducing taxon is indicated in orange. The tree is rooted with Phaeosphaeria chiangraina (MFLUCC 13-0231) and P. musae (MFLUCC 11-0133).

Known distribution - Italy, Trento Province, Marilleva, on stems of Aconitum vulparia (Ranunculaceae) Mapook et al. (2016), Uzbekistan (this study). 
Notes - Our strain (HKAS112715), morphologically resembles Nodulosphaeria aconiti (MFLUCC 13-0728) (Table 2). The pairwise identity of each gene region indicates a higher identity between our strain HKAS112715 and N. aconiti MFLUCC 13-0728 (ITS: 0.9365609, LSU: 1.0000000, SSU: 0.9563492 and tefl- $\alpha$ : 0.9124726). Further, phylogeny indicates moderate ML support and higher BYPP support between two strains of $N$. aconiti MFLUCC 13-0728 and N. aconiti KUMCC 20-0333 (ML/BYPP: 68\%/0.99). Therefore, we identify our strain as $N$. aconiti. Our morphological study reports terminal appendages of $N$. aconiti, which was not reported in previous studies (Mapook et al. 2016).
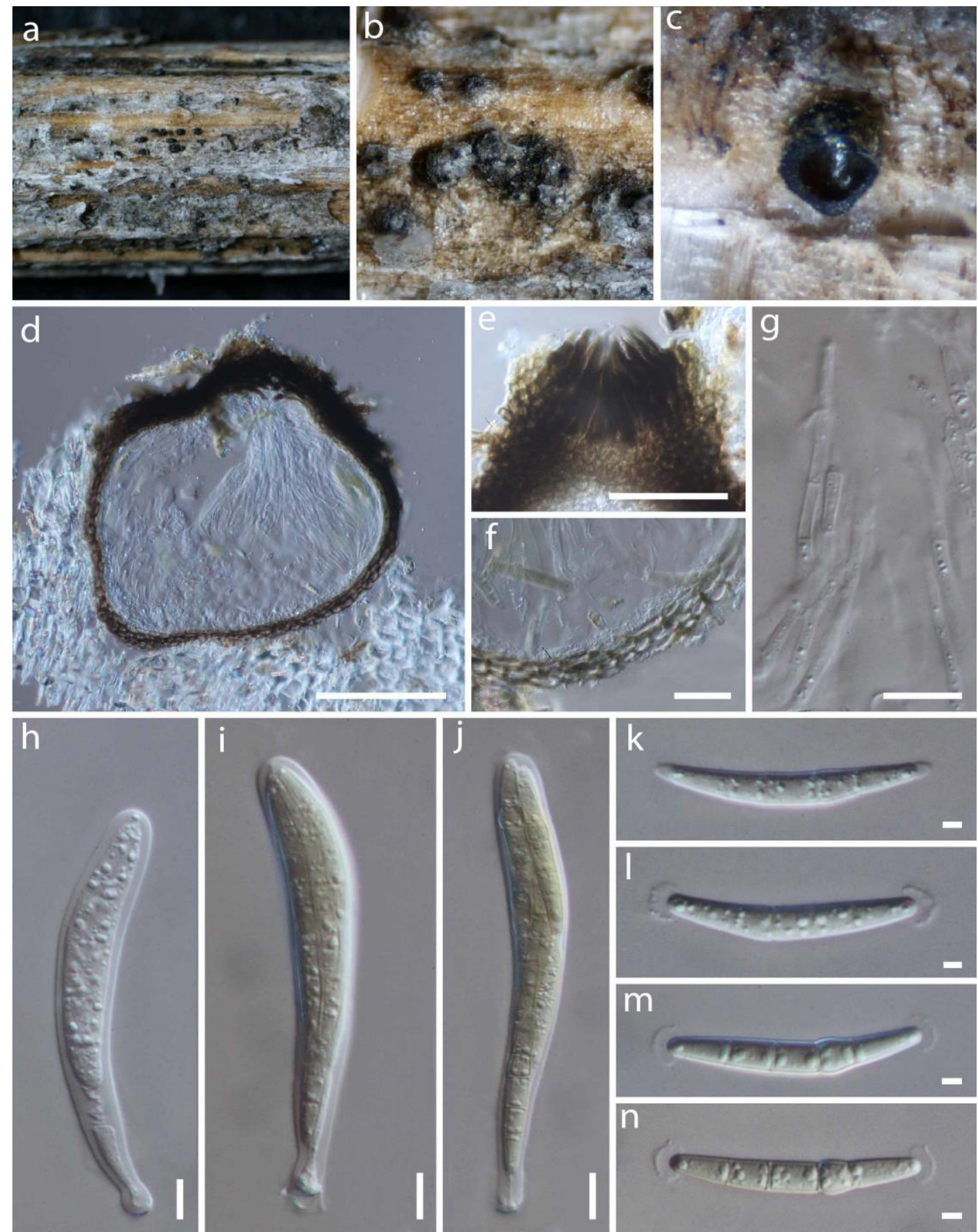

Fig. 2 - Nodulosphaeria aconiti (HKAS112715, a new host record). a, b Appearance of ascomata on host substrate. c Horizontal section of an ascoma. d Vertical section through an ascoma. e Closeup of ostiole showing dark brown setae. f Peridium. g Pseudoparaphyses. $\mathrm{h}-\mathrm{j}$ Immature and mature asci. k-n Ascospores. Scale bars: $d=20 \mu \mathrm{m}, \mathrm{e}=10 \mu \mathrm{m}, \mathrm{f}=10 \mu \mathrm{m}, \mathrm{g}=10 \mu \mathrm{m}, \mathrm{h}-\mathrm{j}=10 \mu \mathrm{m}$, $\mathrm{k}-\mathrm{n}=5 \mu \mathrm{m}$. 
Table 1 Taxa used in the phylogenetic analyses and their GenBank accession numbers. The newly generated sequences are indicated in bold

\begin{tabular}{|c|c|c|c|c|c|c|}
\hline \multirow[t]{2}{*}{ Species } & \multirow[t]{2}{*}{ Culture accession no. } & \multicolumn{5}{|c|}{ GenBank accession no. } \\
\hline & & ITS & LSU & SSU & tef1-a & $r p b 2$ \\
\hline Allophaeosphaeria cytisi & MFLUCC 15-0649 & KT306947 & KT306950 & KT306954 & N/A & N/A \\
\hline Chaetosphaeronema hispidulum & CBS 216.75 & KF251148 & KF251652 & EU754045 & KF253108 & KF252157 \\
\hline Dematiopleospora mariae & IT1293 & KJ749654 & KJ749653 & KJ749652 & KJ749655 & N/A \\
\hline Entodesmium artemisiae & MFLUCC 14-1156 & KT315508 & КT315509 & N/A & N/A & \\
\hline Entodesmium rude & CBS 650.86 & N/A & GU301812 & AF164356 & GU349012 & N/A \\
\hline Loratospora aestuarii & JK 5535B & N/A & GU301838 & GU296168 & N/A & GU371760 \\
\hline Muriphaeosphaeria galatellae & MFLUCC 14-0614 & KT438333 & KT438329 & KT438331 & N/A & N/A \\
\hline Nodulosphaeria aconiti & MFLUCC 13-0728 & KU708848 & KU708844 & KU708840 & KU708852 & KU708856 \\
\hline Nodulosphaeria aconiti & KUMCC 20-0333 & MZ157024 & MZ157025 & MZ157030 & MZ246832 & N/A \\
\hline Nodulosphaeria derasa & CBS 184.57 & $\mathrm{~N} / \mathrm{A}$ & N/A & GU456299 & GU456275 & N/A \\
\hline Nodulosphaeria hirta & MFLUCC 13-0867 & KU708849 & KU708845 & KU708841 & KU708853 & N/A \\
\hline Nodulosphaeria scabiosae & MFLUCC 14-1111 & KU708850 & KU708846 & KU708842 & KU708854 & KU708857 \\
\hline Nodulosphaeria senecionis & MFLUCC 15-1297 & KT290257 & KT290258 & KT290259 & N/A & N/A \\
\hline Nodulosphaeria spectabilis & MFLUCC 14-1112 & KU708851 & KU708847 & KU708843 & KU708855 & N/A \\
\hline Nodulosphaeria digitalis & MFLUCC 17-2418 & MG891749 & MG891750 & MH791042 & MH791041 & N/A \\
\hline Nodulosphaeria digitalis & MFLUCC 15-2716 & KU058710 & KU058720 & N/A & N/A & N/A \\
\hline Nodulosphaeria guttulatum & MFLUCC 15-0069 & KY496746 & KY496726 & KY501115 & KY514394 & N/A \\
\hline Nodulosphaeria italica & MFLU 16-1359 & KX672153 & KX672158 & N/A & N/A & N/A \\
\hline Nodulosphaeria multiseptata & MFLUCC 15-0078 & KY496748 & KY496728 & N/A & KY514396 & N/A \\
\hline Nodulosphaeria sambuci & MFLUCC 15-0068 & KY496742 & KY496721 & KY501112 & N/A & N/A \\
\hline Ophiobolus cirsii & MFLUCC 13-0218 & KM014664 & KM014662 & KM014663 & N/A & N/A \\
\hline Ophiobolus erythroporus & MFLU 12-2225 & $\mathrm{N} / \mathrm{A}$ & KM014665 & KM014666 & N/A & N/A \\
\hline Ophiosimulans tanaceti & MFLUCC 14-0525 & KU738890 & KU738891 & KU738892 & N/A & N/A \\
\hline Phaeosphaeria chiangraina & MFLUCC 13-0231 & KM434270 & KM434280 & KM434289 & KM434298 & KM434307 \\
\hline Phaeosphaeria musae & MFLUCC 11-0133 & KM434267 & KM434277 & KM434287 & KM434296 & KM434304 \\
\hline Phaeosphaeriopsis dracaenicola & MFLUCC $11-0157$ & KM434273 & KM434283 & KM434292 & KM434301 & KM434309 \\
\hline Phaeosphaeriopsis dracaenicola & MFLUCC 11-0193 & KM434274 & KM434284 & KM434293 & KM434302 & KM434310 \\
\hline Phaeosphaeriopsis glaucopunctata & CBS 653.86 & KF251199 & GQ387592 & GQ387531 & N/A & KF252206 \\
\hline Phaeosphaeriopsis glaucopunctata & MFLUCC 13-0220 & KJ522474 & KJ522478 & KJ522482 & N/A & N/A \\
\hline Phaeosphaeriopsis glaucopunctata & MFLUCC 13-0265 & KJ522473 & KJ522477 & KJ522481 & N/A & N/A \\
\hline Phaeosphaeriopsis triseptata & MFLUCC 13-0271 & KJ522475 & KJ522479 & KJ522484 & N/A & KJ522485 \\
\hline Phaeosphaeriopsis triseptata & MFLUCC 13-0347 & KJ522476 & KJ522480 & KJ522483 & N/A & KJ522486 \\
\hline Premilcurensis senecionis & MFLUCC 13-0575 & KT728365 & KT728366 & $\mathrm{N} / \mathrm{A}$ & N/A & N/A \\
\hline Sulcispora pleurospora & MFLUCC 14-0995 & KP271443 & KP271444 & KP271445 & N/A & N/A \\
\hline
\end{tabular}


Table 2 Synopsis of Nodulosphaeria species with some similar morphological features discussed in this study

\begin{tabular}{|c|c|c|c|c|c|c|c|}
\hline Species & $\begin{array}{l}\text { Ascomata } \\
(\mu \mathrm{m})\end{array}$ & $\begin{array}{l}\text { Ascomata } \\
(\mu \mathrm{m})\end{array}$ & $\begin{array}{l}\text { Asci size } \\
(\mu \mathrm{m})\end{array}$ & $\begin{array}{l}\text { Ascospores size } \\
(\mu \mathrm{m})\end{array}$ & Septation & $\begin{array}{l}\text { Host association } \\
\text { family }\end{array}$ & $\begin{array}{l}\text { Source } \\
\text { references }\end{array}$ \\
\hline $\begin{array}{l}\text { N. aconiti } \\
\text { (KUMCC 20-0333) }\end{array}$ & $\begin{array}{l}160-230 \times 180- \\
250\end{array}$ & $10-20$ & $60-100 \times 8-12$ & $30-36 \times 3-4$ & $\begin{array}{l}\text { 4-septate, with } \\
\text { terminal appendages }\end{array}$ & Compositaceae & This study \\
\hline $\begin{array}{l}\text { N. aconiti } \\
\text { (MFLUCC 13-0728) }\end{array}$ & $\begin{array}{l}198-210 \times 113- \\
142\end{array}$ & $11-16$ & $58-83 \times 9-10$ & $29-33 \times 4-5$ & $\begin{array}{l}\text { 4-septate, without } \\
\text { terminal appendages }\end{array}$ & Ranunculaceae & $\begin{array}{l}\text { Mapook et al. } \\
(2016)\end{array}$ \\
\hline
\end{tabular}

\section{Discussion}

Alternaria, Aposphaeria, Asteromella, Camarosporium, Comoclathris, Coniothyrium, Cucurbitaria, Didymosphaeria, Leptosphaeria, Lophiostoma, Ophiobolus, Phaeosphaeria, Phoma, Plenodomus, Pleospora, Pyrenochaeta, Pyrenophora, Stegonsporium, Stemphylium, Trematosphaeria and Venturia are also reported from Artemisia sp. in Southwestern Europe, South Asia and Central Asia. (Farr \& Rossman 2021). Nodulosphaeria aconiti was also found on Aconitum vulparia (Ranunculaceae) from Italy (Mapook et al. 2016). In our phylogenetic analysis, we omitted N. aquilegiae (MFLU 17-1273) and N. thalictri (MFLU 17-1241) due to the low identities of the NCBI blast results with other strains in Nodulosphaeria. Further, rpb2 gene is absent in our strain. Hence, we assume that the absence of the rpb2 gene results in the moderate ML bootstrap support between N. aconiti (MFLUCC 13-0728) and our strain.

\section{Acknowledgements}

P. Pasouvang would like to thank the Mae Fah Luang grant; Faculty of Agriculture National University of Laos, NUOL and Improved Sanitary and Phytosanitary (SPS); Handling in the Greater Mekong Subregion (GMS); ADB project is partly support for PhD fellowship fund (project No. OPN. 4019); Kunming Institute of Botany for the help with molecular work. Yusufjon Gafforov thanks to Ministry of Innovative Development of the Republic of Uzbekistan (Project No. P3-2014-0830174425 and P3-20170921183) for research support.

\section{References}

Arzanlou M, Crous PW. 2006 - Phaeosphaeriopsis musae M. Arzanlou and Crous, sp. nov. Fungal Planet: A Global Initiative to Promote the Study of Fungal Biodiversity, 9.

Barr ME. 1979 - A classification of Loculoascomycetes. Mycologia 71, 935-957.

Carson ML. 2005 - Yield loss potential of Phaeosphaeria leaf spot of maize caused by Phaeosphaeria maydis in the United States. Plant Disease Journal 89, 986-988.

Clements FE, Shear CL. 1931 - Genera of fungi, 2nd edn. H.W. Wilson, New York.

Farr DF, Rossman AY. 2021 - Fungal Databases, U.S. National Fungus Collections, ARS, USDA. From https://nt.ars-grin.gov/fungaldatabases/ (Retrieved on January 25, 2021) 
Gafforov Y, Phookamsak R, Jiang HB, Wanasinghe DH et al. 2019 - Ophiobolus hydei sp. nov. (Phaeosphaeriaceae, Ascomycota) from Cirsium and Phlomoides in Uzbekistan. Botany 97, 671-680.

Hall TA. 1999 - BioEdit: a user-friendly biologicalsequence alignment editor and analysis programfor Windows 95/98/NT. In Nucleic Acids Symp. Ser 41, 95-98.

Holm L. 1957 - Etudes taxonomiques sur les pléosporacées. Symb Bot Upsaliens 14, 1-188.

Holm L. 1961 - Taxonomical notes on Ascomycetes. IV. Notes of Rbh. Sven Bot Tidskr 55, 6380.

Hongsanan S, Hyde KD, Phookamsak R, Wanasinghe DN et al. 2020 - Refined families of Dothideomycetes: Dothideomycetidae and Pleosporomycetidae. Mycosphere. 11, 1553-2107.

Huelsenbeck JP, Ronquist F. 2001 - MRBAYES: Bayesian inference of phylogenetic trees. Bioinformatics 17, 754-755.

Hyde KD, Jones EBG, Liu JK, Ariyawansa HA et al. 2013 - Families of Dothideomycetes. Fungal Diversity 63, 1-313.

Index Fungorum. 2021 - Index Fungorum. Available from:

Katoh K, Rozewicki J, Yamada KD. 2019 - MAFFT online service: multiple sequence alignment, interactive sequence choice and visualization. Briefings in bioinformatics 20(4), 1160-1166.

Kuraku S, Zmasek CM, Nishimura O, Katoh K. 2013 - aLeaves facilitates on-demand exploration of metazoan gene family trees on MAFFT sequence alignment server with enhanced interactivity. Nucleic acids research. 41(W1), W22-W28.

Li WJ, Bhat DJ, Camporesi E, Tian Q et al. 2015 - New asexual morph taxa in Phaeosphaeriaceae. Mycosphere. 6, 681-708.

Liu YJ, Whelen S, Hall BD. 1999 - Phylogenetic relationships among ascomycetes: evidence from an RNA polymerase II subunit. Mol Biol Evol 16, 1799-1808.

Mapook A, Boonmee S, Ariyawansa HA, Tibpromma S et al. 2016 - Taxonomic and phylogenetic placement of Nodulosphaeria. Mycological Progress. 15, 1-15.

Miller MA, Pfeiffer W, Schwartz T. 2008 - Creating the CIPRES science gateway for inference of large phylogenetic trees. Proceedings of the Gateway Computing Environments Workshop (GCE), November 14, 2010, New Orleans, Louisiana, 1-8.

Nylander JAA. 2004 - MrModeltest 2.0. Program distributed by the author. Evolutionary Biology Centre, Uppsala University.

Pem D, Gafforov Y, Jeewon R, Hongsanan S et al. 2018 - Multigene phylogeny coupled with morphological characterization reveal two new species of Holmiella and taxonomic insights within Patellariaceae. Cryptogamie Mycologie. 39(2), 193-209.

Pem D, Jeewon R, Gafforov Y, Hongsanan S et al. 2019a - Melanocamarosporioides ugamica gen sp. nov., a novel member of the family Melanommataceae from Uzbekistan. Mycological Progress, 18, 471-481.

Phookamsak R, Liu JK, McKenzie EHC, Manamgoda DS et al. 2014 - Revision of Phaeosphaeriaceae. Fungal Diversity 68, 159-238.

Phookamsak R, Wanasinghe DN, Hongsanan S, Phukhamsakda C et al. 2017 - Towards a natural classification of Ophiobolus and ophiobolus-like taxa; introducing three novel genera Ophiobolopsis, Paraophiobolus and Pseudoophiobolus in Phaeosphaeriaceae (Pleosporales). Fungal Diversity 87, 299-339.

Quaedvlieg WGJM, Shin HD, Barretto RW, Alfenas AC et al. 2013 - Sizing up Septoria. Studies in Mycology 75, 307-390.

Rabenhorst GL. 1858 - Klotzschii herbarium vivum mycologicum sistens fungorum per totam Germaniam crescentium collectionem perfectam. Editio nova. Centuria VIII. 701-800.

Rambaut A, Drummond AJ. 2007 - Tracer v1.4, Available from: http://beast.bio.ed.ac.uk/Tracer (Accessed on April 1, 2019).

Rambaut A. 2012 - FigTree v1.4: Tree figure drawing tool.

Rannala B, Yang Z. 1996 - Probability distribution of molecular evolutionary trees: A new method of phylogenetic inference. Journal of Molecular Evolution 43, 304-311. 
Rehner S. 2001 - Primers for elongation factor 1- $\alpha$ (EF1- $\alpha)$.

Senanayake IC, Rathnayake A, Marasinghe DS, Calabon MS et al. 2020 - Morphological approaches in studying fungi: collection, examination, isolation, sporulation and preservation. Mycosphere 11, 2678-2754.

Shoemaker RA. 1976 - Canadian and some extralimital Ophiobolus species. Canadian journal of botany 54, 2365-2404.

Shoemaker RA. 1984 - Canadian and some extralimital Nodulosphaeria and Entodesmium species. Canadian journal of botany 62(12), 2730-2753.

Stamatakis A, Hoover P, Rougemont J. 2008 - A rapid bootstrap algorithm for the RAxML Web servers. Systematic Biology 57, 758-71.

Stamatakis A. 2014 - RAxML version 8: a tool for phylogenetic analysis and post-analysis of large phylogenies. Bioinformatics 30, 1312-1313.

Stoykow DY. 2004 - A contribution to the study of Leptosphaeriaceae and Phaeosphaeriaceae (Pleosporales) in Bulgaria. I. Mycologia Balcanica 1, 125-128.

Tibpromma S, Hyde KD, Jeewon R, Maharachchikumbura SSN et al. 2017 - Fungal diversity notes 491-602: taxonomic and phylogenetic contributions to fungal taxa. Fungal Diversity 83, 1261.

Vilgalys R, Hester M. 1990 - Rapid genetic identification and mapping of enzymatically amplified ribosomal DNA from several Cryptococcus species. Journal of bacteriology 172, 4239-4246.

Wanasinghe DN, Jeewon R, Peršoh D, Jones EBG et al. 2018 - Taxonomic circumscription and phylogenetics of novel didymellaceous taxa with brown muriform spores. Studies in Fungi 3, $152-175$.

Wanasinghe DN, Wijayawardene NN, Xu JC, Cheewangkoon R et al. 2020 - Taxonomic novelties in Magnolia-associated pleosporalean fungi in the Kunming Botanical Gardens (Yunnan, China). Plos One 15: e0235855.

White TJ, Bruns T, Lee S, Taylor J. 1990 - Amplification and direct sequencing of fungal ribosomal RNA genes for phylogenetics. PCR protocols: a guide to methods and applications, Academic, San Diego, 315-322.

Wijayawardene NN, Hyde KD, Al-Ani LKT, Tedersoo L et al. 2020 - Outline of Fungi and fungus-like taxa. Mycosphere. 11, 1060-1456.

Wijayawardene NN, Hyde KD, Rajeshkumar KC, Hawksworth DL et al. 2017 - Notes for genera: Ascomycota. Fungal diversity. 86, 1-594. 